Scottish

\title{
A journey to Tashkent
}

\section{Captain A.C. Yate}

To cite this article: Captain A.C. Yate (1891) A journey to Tashkent, Scottish Geographical Magazine, 7:2, 57-75, DOI: 10.1080/14702549108554704

To link to this article: http://dx.doi.org/10.1080/14702549108554704

\section{曲 Published online: 30 Jan 2008.}

Submit your article to this journal

山 Article views: 13

Q View related articles $₫$ 


\title{
THE SCOTTISH \\ GE O GR AP H IC A L
}

M A GAZINE.

\author{
A JOURNEY TO TASHKENT. \\ (Read at Meeting of Sociely, Edinburgh, December 12, 1890.) \\ By Captain A. C. Yate, \\ Bombay Staff Corps. \\ (With a Map.)
}

IT is not necessary here to enlarge upon the difficulty of obtaining permission to visit Russian Central Asia. All the latest visitors to, and writers on, that country dwell upon it. Not a few Englishmen have been turned back. When I came from India to Europe in June, the last thing I expected to do was to go to Tashkent. However, at the end of July last, I saw in the columns of the Morning Post and the Independance Belge that an excursion to Tashkent was to be organised at Paris by the Wagons-Lits Company. Even then I looked upon my being allowed to go as very problematical. However, I consulted Colonel Mark Bell, V.C. (whom every one knows as the foremost of military travellers in Asia at the present time), and Colonel the Honourable Reginald Talbot, Military Attaché at Paris, who went as far as Samarkand in 1888. Acting on their advice, I communicated with the Wagons-Lits Company, and, after a month of writing and telegraphing, I at last, at Odessa on 6th September, received from St. Petersburg, by telegram, the required permission to enter Transcaspia. Political reasons, with which every one is well acquainted, have for the present effaced the memories of 1812 and 1854-56, and united France and Russia; so the French now rather monopolise the privilege of touring in Russian Central Asia. Almost all of them come back and write books. With them no praise is too high, no admiration too great, for Russia's mission as an Asiatic civiliser. As an antidote to this, it is advisable to read the book written in 1876 by Eugène Schuyler, the Secretary to the United States Legation in St. Petersburg. Mr. George Curzon, too, has some appropriate remarks in his recent work on Central Asia (pp. 7-8), on the characteristics

VOL. VIr. 
of French Central Asian literature. The last two years have produced three books on Russian Central Asia by Englishmen-viz., by Colonel Le Mesurier, R.E., the Honourable George Curzon, M.P., and Mr. Dobson, the St. Petersburg correspondent of The Times. With such books to consult, we need hardly turn to French writers. Of late years few names have been more prominent in this field of literature than that of Mr. Charles Marvin, whose death in London was announced to us on Friday last. His intimate knowledge of the Russian language and people gave him advantages that other writers, though having a sounder appreciation of the real state of affairs in Central Asia, did not possess. It is not for me here to give any sketch of Central Asian literature. I can only refer my hearers to Mr. Curzon, who gives a list of books on the subject that fills twenty-seven pages, and adds that it might have been enlarged tenfold. We should he cantious about adding to a bulk so vast.

The honour of organising the first personally-conducted tour to Central Asia has fallen to a French company. Messrs. Cook and Gaze may have had all the will to undertake it; but that part of the world is at present not open to English enterprise of any lind. I have always understood that I have had to thank the friendly relations existing between General Annenkoff, the director of the Transcaspian Railway, and the chief of the International Sleeping Car Company for the pleasant trip to Tashkent that I made this autumn. I have certainly to thank the former for unvarying kindness and courtesy from the day that I landed at the port of Uzunada (the western terminus of the Transcaspian Railway) to the day that I re-embarked there. This was the second excursion along the Transcaspian Railway organised by the Wagons-Lits Company, the first being in 1888. I may mention that another one will probably be arranged for next autumn, and, if so, that the starting-point will be Tiflis or Baku, and not Paris. This will be a great improvement. Any one can go from Paris to Baku and back. The difficulty is to get farther. We Englishmen certainly ought to avail ourselves of these Wagons-Lits Company's excursions; and yet this year our party consisted of only three English and two French people. A man has only to send in his application to go and a cheque for the cost of the trip, and the company does the rest. I paid $f 84$ from Tiflis to Tashkent and back, everything included, except wine and washing. For that sum I have seen the first Exhibition ever held, I believe, in Asia. Considering the size, population, commerce, manufactures, and revenue of our Indian Empire, I do not think that we should have allowed Russian Turkistan to set India an example in the matter of Exhibitions. However, we have done so. India has a population of $250,000,000$, according to the census of 1881 . The census of 1891 will probably show a population of $270,000,000$. The revenue of India is about $£ 70,000,000$. Against this Russian Turkistan, Transcaspia, and the subject states of Khiva and Bokhara can show a population of from five to six millions only. As for the revenue, we know that there is a heavy annual deficit, probably amounting to half-a-million; and yet money is forthcoming for an Exhibition. It is one of the curious features of Russian administration that while money is not forthcoming for ordinary wants, such as roads and 
railways in European Russia, improved prisons in Siberia, roads in Central Asia, etc., the 'Tsar's Government always have funds for extraordinary needs, such as the Siberian Railway, the construction of which -if report be true-has not only been sanetioned but also commenced.

There is no longer much romance about travel in Transcaspia and Turkistan. When, in 1863, Vambéry made the tour of Khiva, Bokhara, Samarkand, and Herat, in the garb of a dervish, and when O'Donovan penetrated, in 1881, among the Tekes of Merv, there was romance and risk in that. Nowadays it is a simpler undertaking to visit the tomb of Tamerlane at Samarkand, and the scene of the tragic fate of Stoddart and Conolly at Bokhara, than it was less than a century ago to post from York to London. The Turkoman and Uzbek of to-day are more innocuous than the British highwayman of the last century. No part of the old coach-road from York to London is half so barren, bleak, and desolate as is the Galodnaya steppe between Samarkand and Tashkent. A pair of pistols was a sine qud non for the former; the latter may be now traversed without so much as a derringer. The Russians like to keep. all this security for themselves and their pro tem. friends, the French. I did meet near Jizak an Austrian lady bound for Tashkent and thence (I heard) viô Kuldja to China. She talked English excellently, and expressed great surprise at meeting an Englishman there. I did not think it necessary to remark that an Austrian was an equally rara avis in those climes. There are those who argue that because women can travel in a certain locality, therefore comfort and security are there. By no means. Women are as enduring and as adventurous as men. We may instance Lady Baker, Miss Bird, this Austrian lady whom I have just mentioned-who, alone with a courier, intended to reach (viâ Kuldja and China) the Pacific-Mrs. Littledale, Madame Dieulafoy, and others. One of the party with whom I journeyed from Baku to Samarkand in September last was a Frenchwoman. On my return from Tashkent I came across a Russian lady, who was sharing a tarantass from Tashkent to Samarkand with a Russian officer. The two were simply for the time being compagnons de voyage; but the lady took the lead. She bullied the driver, hectored the post-house master, and never allowed her companion to interfere. She had a masterful energy, and a freedom of speech and of manner, of which many men might have been proud.

I found some difficulty, on the 17th September last, in getting on board the steamer of the Mercury and Caucasus Company at Baku, bound for Uzunada. The Russian Minister of Finance, M. Vyshnegradsky, was a passenger. The only gangway to the first-class cabin was covered with a carpet in honour of his High Excellency, and that carpet was not to be profaned with the dirt off humbler boots. It was intimated to me that I might get on board by the backstairs. After a moment's reflection, I decided that I would not go on board by the backstairs, so I took that earpet by storm. M. Vyshnegradsky having been conducted and received on board with that ceremony which is the due of eminent men-and there is no doubt that he is an eminent man and an able financier-we set sail at 7 P.M.

Nine years ago I remember Baku not half the size it is now, and. 
twenty years ago its site was almost a desert. The Yankee expression. of having "struck ile" is a highly appropriate one. Oil truly lubricates the path to millionairism. Naphtha is utilised in many ways. Petroleum, paraffin, vaseline, lubricating oil and grease, benzine, pomade for the hair, are among its products. The distilled oil is absolutely tasteless, and is admittedly used in the fabrication of salad oils. There is no more reason why it should not be used in the fabrication of butter. It is a mere question of the proper flavouring of the absolutely tasteless grease; it would be quite as palatable as margarine. There are signs that the supply of Baku oil is decreasing. The crude naphtha is much dearer than it used to be. If naphtha fails, it will be a sad blow to the steamers of the Caspian, the Volga, the Aral, and the Oxus, and to the locomotives of the Caucasus and Transcaspia. Coal from Rostoff and Khokand must replace it. The Baku oil-wells are well known. Mr. Marvin, in The Land of Eternal Fire, tells us a good deal about them; and it is not a fortnight since that a very good paper on them appeared in The Scotsman from a manifestly American pen. The chief thing to note now is, that the town of Baku, with its 40,000 or 50,000 people, lives mainly by that oil. If this oil fails, Baku will dwindle away. It will, however, always be an important harbour and railway terminus.

The Caspian is uninteresting. Sand and bare rock are not attractive. The south shore from Astrabad to Astara, and the stretch from Darband to Petrovsk are bearable. The rest is ghastly. The summer heat is damp and apoplectic, and in the winter every harbour in the north is frozen $n$. The sinuous approach to Uzunada, after passing the Krasnovodsk lightship, is dreariness itself: bleak mountains on the left, and bare sand on the right. Uzunada itself wakes up the tourist a little. There are the busy wharves, the wooden houses and sheds and barracks, the water-works, the great piles of bales of cotton, cases, boxes, etc., awaiting shipment or transport to the interior; or perhaps a detachment of time-expired Russian or Cossack troops, being embarked to the sound of musical strains more excruciating than a grinding organ or a hurdygurdy-their regimental band playing them out. They ought to have been playing "Home, Sweet Home;" but I doubt they do not know that lovely air in Russia. I never heard a good military band in Russia, not even of the Guards. The massed bands at the Zariya (evening prayer) at Krasnoe-Selo played, however, very well indeed; there were at least one thousand bandsmen present.

General Annenkoff and every officer of the garrison met M. Vyshnegradsky, the Finance Minister, on the 18th September at Uzunada. When Finance Ministers are on tour and control the grant of millions for railway construction and extension, when important economical, political, strategical, commercial, and financial issues depend on their verdict and pleasure, directors of railways have to be attentive to them. It was therefore very kind of General Annenkoff to notice and think of us as he did, and to give us a carriage all to ourselves. We were six in all, and had a compartment each. This was convenient, as we found the Transcaspian very warm in September. 
It was pleasant sitting about in shirt-sleeves, eating grapes and melons, and drinking hot tea and iced lemonade. We had a restaurant car attached to the train, and plenty of ice. We could have delicious pheasants at every meal, and very cheap. A pheasant costs a shilling or so in Transcaspia. We used to shoot pheasants by the score in 1884-85. Unfortunately our Government ceded most of the best coverts to Russia. It was thoughtless of them to do so. I am surprised that the Amir Abdurrahman should have allowed it. $\mathrm{He}$ can have no sporting instinct. Herat may be of no great moment; but to allow Russia to monopolise all the best pheasant-shooting is too bad. It is bad enough that the Russians in 1885 should have bounced and blustered us out of 15,000 or 20,000 square miles of arid sand and "chul"; but that they should have deprived us of some of the best pheasant-shooting in the world, not to mention tigers and innumerable bears, is inexcusable.

Most people know that Mikhailovsk was the western terminus of the Transeaspian Railway till Uzunada was unearthed (or rather unsanded) and its harbour dredged. Krasnovodsk has a good harbour; but to extend the railway there would have cost, say, half a million. $£ 40,000,000$ to $£ 50,000,000$ are, however, about to be sunk on a Siberian railway; and yet there is scarce one good metalled road in Russia, and scarce one good paved street in any city in Russia. However, the "heathen Chinee" has to be kept in order on the Amur, while the comforts and conveniences of the millions of European Russia can wait. From Uzunada to Mollakari is sandy-great rolling dunes of sand. It looks as if nothing could check that sand. I have seen the great sand-wave of the Registan, near Kandahar, at least 30 feet high, pressing on slowly and steadily eastward, and threatening in future centuries to engulf Kandahar; and I have seen the southern edge of the same between Nushki and the Helmund burying a tall row of willow-trees. I have seen, too, the work that sand is doing east and north-east of the Oxus, near Farab and Karakul; and I have read Sir Douglas Forsyth and Bellew on the shifting sands of Kashgaria. I believe there is no power can stop drifting and shifting sand. The little barriers of saxaul that I saw about Peski and Repetek (near Charjui) were as likely to check drifting sand as a. silken thread is to stop a runaway locomotive. I should say that sand-sweeps, on the principle of the American snow-plough, would be useful on the Transcaspian Railway. It is just 900 miles from Uzunada to Samarkand, and the train traverses that distance in sixty hours, just fifteen miles an hour. After travelling on that line in a carriage thiat shakes one to pieces, it is indeed a treat to come back to old England and do fifty miles an hour in the Scotch express, with a motion so smooth that the sense of motion is almost wanting. I have little doubt that the refreshment car on the Transcaspian railway was a most admirable digester. Motion, they say, is necessary to digestion. I cannot say that that refreshment car was the poetry of motion, but there was plenty of it. The most obstinate morsel could not withstand its disintegrating power. The marvellous thing was that the whole car did not go to pieces. If the contents of a cupful of 
tea or a dishful of soup were not rapidly swallowed, they transferred themselves automatically to the table-cloth and the floor. Still, though I mention these little inconveniences, I wish again to repeat that we were deeply indebted to General Annenkoff for the comfort with which we made the journey from Uzunada to Samarkand and back again.

There is no beanty of scenery near the Transcaspian Railway. Bleak mountains such as the Kuren and Kopet Dagh have at times a transient picturesqueness in the light of the rising and setting sun. The miles of sand-dunes, the miles of waterless waste, the miles of dark arid hillranges, may have some strange power of fascination over the mind, but not of attraction to the eye. One can realise that the railway has had to struggle with the obstinate, defiant sands, with now the absolute dearth of water, and now the untimely attack of violent floods. Mr. Dobson (Russia's Railuay Advance into Central Asia, pp. 139-145) describes these last well. As Bami and Kizil Arvat are approached, the complete desolation is varied by the habitations of the Turkomans, mud forts and walls and houses, streams of water, patches of cultivation and pasture, clumps of trees, etc. There is a certain fascination in thinking that even ten years ago this was almost a terra incognita. But as Geok (or rather Denghil) Tepe is neared, the interest increases. The place where Skobeloff broke the power of the Akhal Tekes in 1881 must be interesting. I have read, and doubtless others have likewise, all that $\mathbf{M r}$. Curzon and Mr. Dobson and Colonel Le Mesurier have to say about it. When I saw the reality, I could only marvel that 35,000 Turkoman men, women, and children could exist there for a month in the face and under the fire of 8000 or 9000 Russians, commanded by one of the most impetuous and intrepid of Russia's generals. The walls average twelve to fifteen feet in height, and enclose a space measuring about 1600 by 800 yards (for exact and detailed measurements I may refer you to Mr. Curzon, p. 77, note). The whole of this enclosed space can be swept by artillery, and perhaps also by infantry (long-range) fire. Thus the Asiaties could only be safe just behind the walls. Indeed they took refuge in pits and holes dug in the ground. There is no ditch worth speaking of, and the flank defences are nit. Yet it held out four weeks. Now compare with this such a town as Herat or Kandahar. The walls of Herat dominate the plain by 100 feet. The mud, hardened like concrete, offers almost greater resistance to artillery projectiles than solid masonry. The Royal Artillery experiments made at Kandahar in 1880 and elsewhere should have taught our gunners this.

Askhabad is an absolutely uninteresting place. Its only importance consists in its being the headquarters of the Transcaspian Government, and that from it the carriage-road viâ Kushan to Mashhad, which is now completed, starts. M. Lessar informed me that in June last he drove along it in a carriage-and-pair. If the Russian Consul-General at Mashhad, M. Vlassoff, wants a change of air and scene, a drive to Kochan or Askhabad is easily managed. Given a good new bridge over the Hari-Rud near Kochan, and one might travel in a post-chaise from Askhabad to Herat. The mountain barrier between Askhabad and Kochan apparently precludes the chance of a railway taking this line. Railway 
communication with Mashhad and towards Herat will be made, naturally, from Dushakh via Sarakhs to Pul-i-Khatun, and thence to Mashhad and Chihil-dukhtar. I think, however, that we may hope with fair reason that the task of reaching Herat by rail will be undertaken by the British Government and from India, and not by the Russian Government from Transcaspia. Leaving out other considerations, such a step is essential for the maintenance of our commercial interests in Afghanistan and Persia. One of the latest Russian proposals is to raise the duty on Indian tea imported into Central Asia, so as to make it more expensive than the caravan teas brought in through Kuldja and Kiakhta. This, of course, will check the importation. We, being all for free trade, take no notice of tariffs $d$ la M'Kinley, whether they emanate from Russia or the United States. With a railway, however, to Herat, and another across Beluchistan and Sistan to Southern Persia, Turkish Arabia, and Asia Minor, we might restore or retain, as the case may be, our supremacy in the trade of Persia and Afghanistan.

Running from Askhabad towards Merv, one passes under the northern cliffs of that great and curious natural fortress, Kalat-i-Nadiri. One or two recent writers have rather tended to spread the idea that this place is strategically valuable. It is not so. Fortified and held as it is by Persians, it is not even strong, far less impregnable. An enterprising European foe would be inside it in no time. But it is not worth fortifying strongly. The stream that flows in at the Arghawan-Shah Gate does not irrigate more than 20 or 30 acres, and it is doubtful if the whole cultivated area in this amphitheatre, measuring about 25 by 6 miles, amounts to 100 acres. Except the Arghawan-Shal stream, which flows along a narrow ravine, and which issues by the Nafta Gate on to the Atak, there is very little water. The pasture for sheep and cattle is not very good or abundant. Kalat commands no important route, although, if held by a determined and bold enemy, it would be an excellent base for harrying the Transcaspian Railway and the communications between Askhabad and Merv. Perhaps its chief value is that its possessor can control to a great extent the water-supply of the Atak. This watersupply is all important to Transcaspia. As the home and abode of Nadir Shah, who emancipated Persia from Afghan domination, and subsequently overran parts of Afghanistan and Northern India as far as Delhi, this spot is dear to the pride of the Persians. The Shah guards it jealously. I spent three very pleasant days there in July 1885, as the guest of the commandant, a Persian nobleman with a fair knowledge of French. Nowadays strangers and foreigners are rigidly exeluded. In $1885 \mathrm{I}$ remember looking down from the top of the northern eliffs of Kalat-iNadiri, over Lutfabad, and Kakha, and Dushakh. I will not say that I looked on it with that interest with which Moses and Aaron gazed on the Promised Land. It was, however, impossible not to feel an attraction for that land of mystery, on which Shakespeare, Abbott, and Burnes, Wolf, Vambéry, and O'Donovan had after all shed but very little lightan attraction that was however warranted, not by such an unsightly expanse of barren steppe, but by its political and geographical interest. For I saw nothing more. Searching for oases on that expanse was like 
looking for needles in trusses of hay. I rode from Gugumaz (the principal village and residence of the commandant of Kalat-i-Nadiri) to the northern searp of this natural fortress, along narrow pathways overhanging steep slopes. My Persian companions were evidently accustomed to it. As $\mathrm{I}$ noted that my outer boot and stirrup were overhanging a quasi-precipice, I felt thankful that I had confidence in my pony. The roads from Mashhad to Kalat-i-Nadiri are the worst I ever traversedand I have tried some fairly bad ones off and on.

From Dushakh the railway runs nearly NE. to Merv, Bairam Ali, Charjui, and the Oxus Bridge. Certainly a good deal of romance and interest attaches to the name of Merv, but when seen it is a disappointing place. Denghil-Tepe is much more interesting. At Merv there is the fort of Kaushid Khan. The area of the fort is probably about the same as that of Denghil-Tepe. One finds that its southern rampart does not exist, and that the other three are so indented and worn away as to be indefensible. Yet the Merv Turkomans in 1881 talked of putting this fort in a state of repair and resisting the Russians. I can quite understand that they abandoned as hopeless the idea of repairing those ramparts, although, if sound, they would be much more defensible than those of Denghil-Tepe. The bazaar, town, and barracks of Merv are miserable structures on the west bank of the Murghab. Kaushid Khan's Fort, enclosing the club, some official buildings, officials' houses, new barracks, the site of the bi-weekly bazaar or fair, and several groups of kibilkas, is on the east bank. It is curious to think of the magic import that attached eight or ten years ago to the word "Merv." The lustre of its medizval prosperity, the romance of O'Donovan's visit to it in ' 81 , and, more than anything else, the universal ignorance about it, had surrounded it with a halo of importance that was ont of proportion to its actual value. Of course it and its neighbour, Bairam Ali, are not to be ignored. Under the administration of Russians, and thanks to works of irrigation, it is possible that the time may come when the Imperial domain at Bairam Ali and the Turkoman lands at Merv will again support a large population. The modern Merv is not on the site of the ancient town, but 18 miles SW. of it. The ancient Merv is close to Bairam Ali. In constructing the Maruchak and Sultan-bend dams, the Russians are merely reviving the irrigation system that has gone to rack and ruin since the Amir Maasum of Bokhara destroyed the city of Bairam Ali about one hundred years ago. The latest reports from Sir Colin Moncrieff and M. Cotard are of a nature to suggest that the Tsar may find his domain at Bairam Ali not so productive as he anticipated. If the dams are, however, a success, the whole of the banks of the Murghab, from Panjdeh to Merv, will be brought under cultivation, instead of being a desert relieved by one or two oases. Good roads will be made from Merv to Maruchak and Chihal-dukhtar, and the valleys of the Murghab, Kushk, and Kochan, and the steppes of Badghis will once more be studded with towns and eities. The remains of these towns are there. If they existed once, they may exist again. If we consider the history of the past twelve hundred years, the Mohammedan conquest, the invasions of Chengiz Khan, Tamerlane, and their successors, the continuous changes of dynasties in 
Bokhara, Merv, Herat, and Persia, with all the tangled web of rivalries, fends, and wars, followed by the lawless domination of the Turkomans during the present century, the desolation of Badghis is not surprising.

The Merv of to-day is no longer the abode of the Turkomans. The aul and kibitka have given place to the bazaars, barracks, and buildings of the Russians. The Turkomans reside in settlements round about, and come in to the bi-weekly fairs held in Kanshid Khan's Fort. Like the Uzbek, the Turkoman seldom condescends to walk. He has a horse to ride, if he can afford it; and if he cannot do that, he has a donkey. From 8 to 11 a.m. they crowd into the fair, bringing their wares. There is a place for everything. There are melons, grapes, and other fruits and vegetables; here are piles of the coats, boots, and sheepskin hats that the Turkomans affect; here again, carpets, saddlebags, Astrakan skins, webs of cloth made of cotton, and of goat or camel-hair. The best camel-hair cloth is very good and very expensive. The Turkoman carpets are famous for durability of colour and material. The Turkomans often make certain parts of their carpets of silk; but a year or two ago the Tekes presented an entire silk carpet to the Tsar.

If the scheme for irrigating Bairam Ali succeeds, that place will soon be greatly changed. Already large storehouses are springing up. A nursery, containing thousands of saplings, covers an area of a square mile or so. Probably, under the influences of a new civilisation, much of the remarkable remains now existing there will be effaced. These remains, whether they are the handiwork of Alexander, or of a race earlier than the date of his invasions, of Iranian or Turanian, of Zoroastrian or Mohammedan origin, whether they bear the name of Alexander, Sultan Sanjar, or Bairam Ali, are well worth seeing. Those who wish to see them would do well to take advantage of the next excursion that goes to Transcaspia. To visit the ruins properly entails a ride of fully 20 miles. We spent four hours hurriedly inspecting them, and could easily have spent four hours more. The bricks of the ruined eity of Bairam Ali are now being used in the new buildings. What appears to be the ruin of greatest antiquity is a circular rampart, about half a mile in diameter, and in some places about 100 feet high above the level of the surrounding country. It encloses a citadel of almost equal height. Excavations were begun here, but discontinued-presumably from want of funds. Alexander is said to have founded a city here; but the Turkomans, who have only occupied this country for fifty years or so, know nothing about its site. More things in Asia are attributed to Alexander than that king and conqueror ever dreamt of. The great landmark of the district is the tomb of Sultan Sanjar, of the Seljuki dynasty, who ruled in the twelfth century A.D. It is second only in size to the mosque of Bibi Khanum, in Samarkand. The original tombstone has been destroyed, and is now replaced by a mud structure that is very unworthy of the edifice in which it stands. The other large ruins are thought to be ice-pits, water reservoirs, and pigeon-houses. I am in favour of the latter. I have seen huge pigeon-houses at Kumesheh, in Persia, and between Herat and Ghorian, that bear some resemblance to those of ancient Merv. It is well to view this great expanse of ruins from some 
commanding point. What was once so populous is all a desert now. If it could be irrigated by races that we now look upon as uncivilised and unenlightened, are the leading English and French engineers to admit their inability to re-irrigate it? Yet such is the purport of paragraphs that are now appearing in the papers. We know that many of the engineering and architectural works of olden times are such as to excite wonder nowadays. We have our steam, pneumatic, hydraulic, and electric contrivances; and the ancients (we suppose) had none of these. That was the age of stone, and this is the age of iron and steel. We rear Forth Bridges and Eiffel Towers, and they reared Pyramids and Babylons. It is difficult, however, to believe that irrigation is a science that was more advanced 1000 years ago than it is now. There is one thing, however, to remember, and that is, that now the water is diverted to the Turkoman and Russian settlements at Yulatan and Kaushid Khan Kalah. This was probably not the case until within the last century. That the Tsar and the Government are in earnest about the repopulation of Bairam Ali is certain. An imperial domain, an extensive nursery-garden, and substantial stone buildings are not established for nothing. In October last, about 100 families of Tunganis or Dungans (as they are variously styled) arrived from Kuldja, for employment at Bairam Ali. These Tunganis are Chinese Mohammedans, like the Panthays of Yunnan. Both alike rebelled against the Chinese Government, some twenty years ago; and both, at a later period, felt the mercilessness of Chinese revenge. Many of the Tunganis found refuge in Russia and of the Panthays in the Shan States and Burma.

In speaking of a trip to Tashkent, one can hardly ignore altogether the Transcaspian Railway, although it has already been well described by Major C. E. Yate, Colonel Le Mesurier, Mr. Curzon, Mr. Dobson, and by several other writers, English, French, and Russian. The length of the line, from Uzanada to Samarkand is 900 miles. It is built to admit of slow traffic only, like most of the lines in European Russia. It will be remembered that not long ago ( $\mathrm{I}$ think in 1889) a serious accident occurred to the Tsar's special. It all came, I am told, of running too fast on a badly-made line. Similar mishaps would presumably occur on the Transcaspian line, if the trains ran too fast. As for the sands, I have already pointed out my reasons for thinking that drift-sand cannot be controlled. After a storm, the line has to be cleared of sand. I was assured that, in the ten years that have elapsed since the line was begun at Mikhailovsk, no serious sand-block has been known. The permanent way has in many places been edged and solidified with saxaul bushes, and with good results. It at least prevents the sand from being blown away and leaving the rails and sleepers all bare. I heard Russians talking of planting trees, and running canals or ditches parallel to the line, from Charjui towards Repetek and Peski (where the sand is worst); but I don't think such projects are practical. Anyhow, they are likely to cost more than they are worth. Near the Oxus, at Charjui, the wind sets pretty steadily from the NE. and NNE. You can tell this by the lay of the sand-drifts, which slope gradually on the north, and abruptly on the south side. For years past the sand has been invading the tract on the 
right bank of the Oxus, form Farab to Karakul. It comes from the Kizil Kum. The sand-drifts extend as far as the eye can see on either side of the railway. It is a tract that is evidently doomed to desolation. In time it will be the counterpart of the tract on the left bank, from Charjui to Peski, which is nothing but an expanse of rolling sand-deserts, studded with saxaul and tamarisk. The average pace of the mail-train on the Transcaspian Railway is 15 miles an hour, including stoppages. It would not be advisable to go quicker, otherwise some of the cars might shake themselves off the line. The gauge is five feet. The ordinary gauge in Great Britain is $4^{\prime} 8 \frac{1^{\prime \prime}}{2}$. The regular trains on the line are three mails each way weekly, and a daily mixed train each way, between Uzanada and Samarkand. There are also goods trains as required. The fuel used in the locomotives is astatki-the refuse of the Baku naphtha, after the extraction by distillation of all its valuable properties. Special trains run for supplying the several stations with water, victuals, and astattic. Most of the stations have reservoirs for water and astatki. The railway buildings are mostly of good solid masonry. The Oxus bridge was finished early in 1888, and is still standing. It is entirely of wood; and trains have to cross it carefully at the rate of four miles an hour. It is two miles long; so the trains take half-an-hour to cross it. Undoubtedly General Annenkoff would gladly see this wooden structure replaced by an iron one; but the bed of the Oxus is so continually shifting, that to sink a large sum of money in an iron bridge that might be left high and dry in a year or two would be rash.

One of the pleasantest days that we spent in Transcaspia was spent with his Excellency General Annenkoff at Amudarya. When we arrived at the railway station early on the morning of the 5th of October we were met by an A.D.C., who told us that General Annenkoff expected us at his house at ten o'clock. The first place the General took us to was the schoolhouse. There were seventy boys and girls, some twenty of whom came every morning from Farab on the right (east) bank of the Oxus by train, returning in the evening. The general remarked to us : "When I start a cantonment anywhere for my railway troops, amongst the first things I construct are a school and a church." The appearance of the Amudarya school was very similar to that of our national schools. The children sang in chorus several Russian airs and hymns, and were catechised by the schoolmistress for the edification of his Excellency. From the schoolroom we went to the barracks, where we found all in apple-pie order and the soldiers standing at attention with a rigidity that Tommy Atkins might envy. On such occasions as these, Russian generals and soldiers always interchange a few stereotyped words of a complimentary nature. In the kitchen of one company we were invited to taste the soup for the soldiers' mid-day meal. It contained meat and potatoes, flour, salt, butter, onions, cabbage, etce, etc., and was excellent. The men of each company manage their own catering, electing one of their number as eaterer. We then were taken to hear the band practise. After this we returned to the road. Bugles were sounded. In ten minutes the railway battalion had turned out and fallen in. Meantime a message was sent to the Turkistan battalion encamped about a mile away. This 
battalion arrived on the pound in parade order in less than an hour. It was not forewarned. It proved to be a battalion that had distinguished itself at the capture of Tashkent in June 1865, and had participated in the ejection of the Afghans from Dash-Kepri on 30th March 1885. The latter feat confers no distinction. It was nothing for Russian infantry armed with Berdans to oust 800 or 900 Afghans armed with Brown Besses. It is true that the Times told the world that a handful of Russians had inflicted a crushing defeat on a vastly superior force of Afghans. But in point of facts our leading journal is as prone to err as others. As far as I can ascertain, the numbers of Russians and Afghans engaged were nearly equal. What General Komaroff did deserve credit for was that with thousands of Turkomans behind him ripe for rebellion, and at the risk of bringing on a war with Great Britain, he attacked and turned the Afghans out of Panjdeh. Nothing succeeds like success. Komaroff suceeeded.

The country from the Oxus at Farab to Charjui is not very interesting. At Karakul red and white wines and cognac are made from the grapes of the country. Some Frenchmen are in charge of the place; but it is understood that General Annenkoff has a personal interest in it. We tasted the wines at his table; and very good they were. General Anneukoff is very keen about the development of Central Asia. He interests himself personally in horse-breeding (from thoroughbred English and Turkoman strains), in wine-growing, and in everything that can further trade, manufacture, and agriculture. He is anxions to throw open the railway and country to foreigners, so as to encourage trade and progress. His schemes for railway extension to Afghanistan are not such as can be or should be encouraged by us. It is currently reported that he will superintend the construction of the Siberian Railway. His antecedents qualify him for it. It stands to reason that the Transeaspian and Siberian Railways must be joined. Regarding the extension of the former, opinions differ. Tashkent being the capital of Turkistan, we would expect the railway to be continued direct from Samarkand to Tashkent. Good authorities, however, think that the first extension will be from Samarkand to Khokand. The importance of the Ferghana District, from a mineral, agricultural, and manufacturing point of view, may account for this. It has a population of 700,000. Semipalatinsk is likely to be the point where the Siberian and Transcaspian lines will meet.

A word or two about the prisons at Bokhara. Of course, I read the description of them by Dobson (pp. 255-7) in 1888. I can only say that, in October 1890 , I saw nothing of the dirt, squalor, or ill-treatment that he describes. I found the prison clean and fairly comfortable. The prisoners were not chained together when we saw them, but the chains were there, and we were shown how the whole row of prisoners could be chained together. The prisoners were docile. We gave them bread and money. We asked one or two about their crimes, and, by their own admission, they were justly undergoing punishment. However, the chief point of interest about the Bokhara prison is the fact that in it (i.e. in a subterranean dungeon or pit now elosed) poor Colonel Stoddart and Captain 
Conolly were perhaps kept. Opinions differ as to whether they were kept in the citadel prison or in the prison I saw. I will state what M. Klem, the Secretary to the Russian Envoy at Bokhara, told me. He said that he had questioned an old Russian trader, who had come to Bokhara in or about 1842 (he died in 1889), and recollected that soon after his arrival two Englishmen were executed on the Righistan. This man stated that the two prisoners (whoever they were) were imprisoned outside, and not inside the citadel. They could only have been Stoddart and Conolly. M. Klem stated very positively that the place where Stoddart and Conolly were kept was in a dungeon under the domed prison that we visited. Mr. Dobson (p. 256) is also of this opinion. No stranger is allowed in the citadel nowadays, and it is not likely that Stoddart and Conolly went there. On the other hand, Khanikoff says the prison was inside the citadel.

During our stay in Bokhara we were the guests of M. Lessar, the Russian Envoy or Diplomatic Agent. We spent two days there, and saw everything. I consider Bokhara one of the unpleasantest and dirtiest cities I ever was in. The population are of the lowest order, and of contemptible physique and appearance. We saw no manufactures there that could touch what we saw at Merv, Samarkand, and Tashkent (both in the bazaars and the Exhibition). No stranger is allowed in the citadel, where live the Amir and Kushbegi. The streets are narrow, and the roads execrable. We drove to and from the railway station to the Residency in carriages. When we met a cart in a narrow lane, great manœuvres were needed to admit of passing. There are few more interesting men to talk to than M. Lessar. He first came to the front in 1882, when he travelled from Sarakhs across Badghis into the Herat valley at Ghorian, and reported that a railway could easily be made to Herat. He has since travelled a good deal in the most waterless tracts of Transcaspia. M. Lessar told us how, at Ghorian in 1882, the Afghans talked of taking him a prisoner to Herat before the Governor. To see the inside of Herat was the height of his ambition. However, the Afghans finally decided not to take him to Herat, and put him across the frontier into Persia, near Kochan. M. Lessar speaks English well, and takes in, among other papers, The Times, Review of Reviews, Public Opinion, and several English magazines.

The Bokhariot troops merit a paragraph to themselves. Every morning the infantry parade on an open space to the north of the city walls. On Saturdays the commander-in-ehief attends, and then the artillery and cavalry parade as well as the infantry. At times the Emir himself looks on from a garden window hard by. He has none of the soldierly spirit of William II. of Germany. He leaves his army entirely to his commander-in-chief. The infantry drill that we saw was strictly original. I never saw anything like it. The uniforms were somewhat similar to the Russian. The guns were mostly pereussion muskets. Bayonets remained always fixed, as with the Russians. Two or three battalions were drilling - some doing battalion, some company drill. One band played in the centre, and gave the time to the whole. Some of the non-commissioned officers carried wands only, no arms. Several of the officers were Afghans, 
and they were among the few really soldierly-looking men of the lot. The men never ceased keeping time to the music. When halted, they always marked time with one leg. The movements in square and to resist cavalry were truly marvellous, and absolutely impossible, or useless, in the face of an enemy. At any cessation in the drill the men lay down here and there, and ate or smoked, the officers reclining on rugs in the shade. We spoke to one or two officers, and found them most civil. There was a great deal of inattention and staring abont in the ranks; still the men drilled well. In fact, that is about all they are good for. They looked as if they had no pluck and no stamina.

Samarkand is a very different place from Bokhara, which is the ne plus ultra of squalor. The climate is exceedingly pleasant in autumn, though doubtless warm in the summer and cold in winter. Tashkent has a similar climate. The old town of Samarkand is small compared with Bokhara, but the bazaars and streets are more open and airy. There is nothing to buy except silk. We spent some time in a silk factory. The huge edifices of Samarkand, the tomb of Tamerlane, the mosque of Bibi Khanum, and the three medresses of the Righistan, are unequalled in Central Asia. I cannot agree with Mr. Curzon in speaking of the Righistan as the noblest public square in the world. I would rather look on the Louvres from the Tuileries gardens, or on that grand square in Vienna enclosed by the Palace, House of Parliament, Museum, and other splendid buildings. I have not a great admiration for the effect of the Oriental tile-work, at least in its ruined state. I must admit that some of the designs are very effective, and certainly nothing like them is produced nowadays. It is a defunct species of architectural ornament. Globe-trotters think nothing of pilfering an old tile, if they get the chance; the mullas in consequence watch all visitors closely. One Frenchman we met inveighed in strong terms against the Vandalism that prompted travellers to despoil the fine specimens of Mohammedan architecture. Nevertheless, when he left Samarkand to return to France, several tiles were found in his room. He had forgotten to carry his spoil with him. I was surprised to note that Russians and Frenchmen never removed their hats when they entered Mohammedan shrines and mosques. We Englishmen always did so. Mohammedans always remove their shoes when they enter one of their religious edifices. I felt that to remove one's hat was at least due to the memory of Taimur-lang, his sons and grandsons, and his ministers and mullas, all of whom lie buried in what is known as "Gur-Amir," or the Tomb of Taimur-lang.

To any Anglo-Indian who knew Afghanistan and Afghan politics well it was interesting to meet and talk to the Afghan refugees, with Surdar Mohammed Ishak Khan, the late Governor of Afghan Turkistan. As you will remember he rebelled against his cousin, the Amir Abdurralman, two or three years ago, and, being defeated, fled into Russian territory with a large following. There he is still. One of his followers turned out to have spent a year with the Afghan Boundary Commission as a mehmandar-in other words, a victualling agent. He knew all the members of it well by name. I was interested to meet him, though I left the Commission before he joined it. The Russian cantonment at Samarkand 
covers several square miles of ground. There is a well-wooded park, great broad roads lined with trees, and the houses are all buried and almost lost amid trees and gardens. There is a large fort on the top of a rising ground overlooking the native city, and separating it from the cantonment. The summer barracks are three or four miles away, near the railway station. The troops occupy them in summer only. They are constructed very simply and cheaply, and in marked contrast to the palaces we erect for our soldiers in India. For years past there has been a tendeney to molly-coddle the private soldier (not the officers, mind you) in India. The medical men are mainly responsible for it. One of the many good works that Sir Frederick Roberts is now doing in India is taking the British soldier out of the cotton-wool in which others have been packing him up. I have over and over again read the remark that the Russian soldier is better fitted to bear the Asiatic climate than the British. But I do not believe that the Briton, who has proved his ability to advance and struggle in every part of the world, is to be beaten by any European in his power of enduring climatic vicissitudes. If, however, the British soldier is molly-coddled, and the Russian soldier is inured to hardship, the latter will prove the best man in time of trial. I and my companions were very much impressed by the healthy physique and manly, cheery, look of the Russian soldiers whom we saw in Transcaspia and Turkistan. They were real good stuff for soldiering. It is somewhat amusing to think of our soldiers, many of whom if they were in England now would be glad to avail themselves of General Booth's scheme for aiding the unemployed, reclining luxuriously under punkahs in a darkened room in India and having servants to wait upon them. I can assure you that the Russians in Asia have no such nonsense. There is another thing that one notices in Central Asia: within the twenty-five years that the country has belonged to Russia, all the inhabitants of the towns, and many of those in the country, have learned Russian. In India we pay our officers and officials to learn all sorts of outlandish dialects, which, in nine cases out of ten, they forget as fast as they can. Russia pays nothing, but makes the natives understand that the sooner they learn Russian the better for their interests. This is the right principle, for it tends to reduce the number of languages and dialects spoken in the world. What is the use of inventing Volapük, if the empire on which the sun never sets encourages the use of every barbarous language that is spoken in its dominions? They may be most attractive to ethnologists, philologists, and other scientists, but for a practical Government to pay a premium for their preservation is a mistake. It is well known that barbarous races die out as civilisation advances. Barbarous languages should do the same.

As the object of this paper is partly to encourage others to visit Bokhara, Samarkand, and Tashkent, I think a few words about hotels will be appropriate. At Bokhara, as I have mentioned, we were the guests of M. Lessar, and afterwards, thanks to General Annenkoff's courtesy, lived in our railway carriage. Samarkand is rich in hotels, but none of them can be styled first-class. Lifts, electric bells, electric lighting, and such like improvements, have not come in. I should say that the Central Asian hostelries answered more to what in Paris is 
called an hôtel garni-a place where you can lodge but not board. However, in Samarkand, the difficulty was-not to find the wherewithal to refresh the inner man, but the wherewithal to cleanse the outer man. At Tashkent the hotel kept up two or three brass basins for the use of the nine or ten inmates. There was no washing apparatus in the rooms, there was no lavatory, there was not even a pump. If a man arrived at the conclusion that he had at least fairly earned a wash, he put his head out of the door (there were no bells), and shouted for the basin and water. Hip-baths are as yet unknown in Turkistan. In other respects the hotel was clean and the proprietors (sarts) obliging. I have had some experience of hotels, and I think that, all considered, the proprietor of the Hôtel de l'Europe at Samarkand should be awarded the palm for extortion. At St. Petersburg I have paid extortionate prices for good food and wine; at Samarkand we paid them for bad food and wine. In Turkistan every staple food is excessively cheap, and that is not the case in large European cities. Samarkand beer and wine are drinkable, but neither choice nor costly. Nevertheless our bill amounted to about 25s. per head per diem. It was pure extortion. When we saw this bill, we realised the advantage we had enjoyed at Tashkent in being able to use the military club. We got good wine and food there at most moderate prices. Such prices are, I imagine, indispensable to the incomes of all the junior Russian officers.

The most interesting part of our journey was certainly that from Samarkand to Tashkent and back. It has to be done in a tarantass with post-horses. A tarantass is a wooden vehicle with or without springs, on four wheels, in which two persons can recline side by side on straw, mattresses, rugs, or any other soft substance. I can assure you that a good deal of padding is required to enable any one to stand thirty to forty hours' jolting. Still, such a journey entails nothing more than some temporary discomfort. It is true that, of our party of five, three shirked the tarantass journey; but, on the other hand, Russian ladies frequently make long journeys in it. The 190 miles from Samarkand is nothing compared to the two or three weeks' journeys done in Siberia. As I have already stated, I met near Jizak an Austrian lady all alone, bound for China vid Tashkent and Kuldja. For means of locomotion she would have to choose between a tarantass, a horse, or a camel. We have recently heard of $\mathrm{Mr}$. and Mrs. Littledale reaching India across the Pamir and the Hindu Kush. I will not go so far as to say the journey in a tarantass from Samarkand to Tashkent is a pleasure. Dirt, dust, flies, heat by day, cold by night, joltings, bad food, etc., are not comforts. The dust at times was hanging so thick round the vehicle that we had great difficulty in breathing. I began to realise what a Central Asian dust-storm might be, when travellers are said to be absolutely suffocated. However, despite these little drawbacks, I hold that the game was worth the candle. The Tashkent Exhibition was very instructive, and it is the one thing that was new that previous travellers had not seen. What with the Finance Minister, M. Vyshnegradsky, the Inspector-General of Prisons, M. Galkin Vrassky, General 
Annenkoff, M. Lessar, and their suites, all visiting Tashkent at once, not to mention private travellers, it was great luck that we got a carriage and horses at all. We have really to thank General Annenkoff for getting them both going and coming. As for the postal officials, for prevarication (not to use a stronger term) even Orientals would find it hard to be even with them. However, at $10 \mathrm{am}$. on the $22 \mathrm{~d}$ September, we got our two tarantasses (one for aurselves and one for baggage) and horses, and off we went. At 9 p.m. we got to Jizak, and were told we could get no horses, as everything was retained for M. Vyshnegradsky. Again we had recourse to General Annenkoff at Samarkand. We wired to him and then went to sleep. At 1 a.m. on the $23 \mathrm{~d}$ we were awakened. and told that telegraphic orders had come and that we might go on. We thanked Annenkoff in our hearts. I can assure you that to have to spend two or three days at a postal station between Samarkand and Tashkent would be little better than imprisonment in jail. From Jizak to the Syrdarya, a distance of 80 miles, the road crosses the Galodnaya Steppe. In the old coaching days no part of England can have been so desolate as this is. And yet it is perfectly safe, safer than even a mail-coach route was from the Sheppards and Turpins of the last century. There is no water, no food, nothing on this steppe. The squalor and dirt of the postal stations is disgusting. The road is what the tarantass and cart wheels make. It is well named the Galodnaya (hungry or famished) Steppe. The Syr-darya is crossed by a swinging bridge, a very fine one. From there onward to Tashkent, a distance of 45 to 50 miles, a road is made in a sort of way. As the Finance Minister was coming, it was being improved a little and watered, i.e. flooded. We benefited by this so far that we escaped some dust, but were liberally bespattered with mud. A little dirt more or less does not matter when you have been for thirty hours in a tarantass on a Central Asian road. We were very thankful when, at 10 p.m. on the $23 \mathrm{~d}$ September, after a thirty hours' drive, we descended at the Moseow Hotel in Tashkent. We immediately requisitioned all the brass basins to be found in the hotel, and surprised the proprietors by the quantity of water we required for our ablutions.

We spent three very pleasant days in Tashkent. The first morning, we drove all round the native town and bazaars; and on the two others, along the Orenburg and Khokand roads. A strong fort here, as at Samarkand, dominates the native town. The Russian troops were located in barracks in various parts of the cantonments. There are fine broad roads, lined with trees and water-courses. Some of the shops are very good. The afternoon of each day we spent at the Exhibition. Last year I visited the Paris Exhibition. I inflnitely preferred the one at Tashkent. Paris was too vast; Tashkent was small, and everything had the interest of comparative novelty. There were to be seen specimens of the products and industries of Turkistan. Cotton is the chief thing. The Russians have paid great attention to the improvement of the cotton grown in Central Asia. American seed has been introduced. It is mainly owing to the export of cotton that the Transcaspian Railway now pays its expenses. About 2000 tons are exported annually. Similar attention has been paid to wine-growing. General Annenkoff took us to see M. vOL. VII. 
Ivanoff's exhibits of local wines. We tasted some half-dozen varieties of red and white wines made in Turkistan. Two (one white and one red) were very fair. We shall, no doubt, have them ere long in the market under the name of white and red Bordeanx. Bessarabia, the Crimea, and the Caucasus also produce good sound wines. Yet few or none of these wines are known in the English market. I was shown at Tashkent Exbibition a long cane, called "Sorgot." The Russians intend to make sugar of it. The sugar-cane does not suit the Turkistan climate. It is expected that "sorgot" will pay well. There are thousands of acres of rice-fields in the valleys of the Zarafshan and the Chirchik, the rivers of Samarkand and Tashkent. General Annenkoff is right in saying that what is needed for the development of Russian Asia are railway extension and improved irrigation. I heard of several projects of irrigation while I was in Turkistan, which will, no doubt, be carried out, and much improve the country. Bokhara is very short of water, as Samarkand now monopolises most of the Zarafshan water. Silk, too, was a prominent feature of the Exhibition. One of the exhibitors was a Corsican, who had brought his eggs and cocoons all the way from Corsica. He proudly remarked that he was the only foreign exhibitor there. Near the entrance were to be seen trophies and reminiscences of the Russian conquest and annexation of Turkistan, which lasted, ronghly, from 1863 to 1873 . The mineralogical section exhibited specimens of coal, brass, lead, iron, salt, sulphur, ozokerit, ete. As Baku oil is likely to fail, it is well that Central Asia produces eoal.

The Exhibition had also its agricultural, piscatorial, and military sections. The Transcaspian Railway was there in miniature. Maps, books, and photos of Central Asia were to be bought; so were beautifully illuminated Persian MSS.; but at a price that might suit the British Museum, but did not suit my pocket. Bokhara silks and embroideries, all sorts of furs, pottery, saddlery, jewellery, brass and leather-work, antique arms and armour, carpets, silks of all sorts, from a handkerchief to a large web. Very fine fruits, such as pears, apples, grapes, and melons, were there. In another part was the cattle and horse show. I saw two really good Turkoman horses there. There were two native bands, one brass and the other string; and the dancing, juggling, and castanetplaying were remarkable. Speaking of Turkoman horses, a Russian officer at Amu-darya showed me two young handsome ones. I am still, however, of opinion that the quality and endurance of the ordinary Turkoman horse are not snperior to those of the Afghan, Persian, Arab, Karabraghi, or other good Âsiatic strains.

And now I have come to the end of my task. There is one thing I wish to say a word about, and that is sport. It is to be hoped that Mr. Littledale on his return will tell us something of his sport on the Pamir and thereabouts. If any one wants good pheasant shooting, let him go to Dushakh and Merv, and then up the Murghab to Maruchak. There, too, he will find the boar and tiger. It is, however, difficult to ride pig in so close a country. One or two tigers were killed by Afghans and Turkomans in 1884-85, and in January 1888 my brother, Major Yate, shot one. There are lots of duck, snipe, and several varieties of par- 
tridge. A sportsman might do worse than spend a few months on the Murghab and the Tejend. If he can get to the Tirband-i-Turkistan he will get good ibex, markhor, and uriyal shooting. The man who aims at the Ovis poli and Ovis ammon must penetrate to the Pamir and Tibet.

In returning from Tashkent we followed the route that we went by, and on the 9th of Oetober we found ourselves at Tiflis. Here I left the rest of the party, and on the 12th left Batum in a tank-steamer (built of steel, specially for the oil trade) for Constantinople. When we were 70 miles from shore $I$ could see 90 or 100 miles off the high ranges (12,000 to 15,000 feet high) of the Caucasus to the NE, and of Armenia towards Ararat to the SE., covered with snow from summit to the horizon. It was a sight not often seen. I reached Constantinople on the 15th, and then was so fortunate as to meet Professor Arminius Vambéry, the doyen of Central Asian travellers. I can conceive no more happy conclusion to a trip to Tashkent than the pleasure of discussing all I had seen with the man whose adventurous journey to Khiva, Bokhara, and Herat in 1863 is so well known.

It is very much to be hoped that in the future the Russians will allow us more facilities for travelling in Central Asia, and that they will more often visit India. We, at least, put no restrictions on them. The visit of the Tsarevitch will, let us hope, induee other Russians to visit India. They are most attentive to us in Central Asia, and we are quite ready to return the compliment in India. I had a conversation on this subject with a Russian Colonel at Tashkent. He mentioned three obstacles to Russian officers visiting India-viz., the want of funds, the difficulty of getting leave, and the fear of arousing our suspicions. The two first the Pussian officers must get over themselves; if they will do so, and come to India, we will show them that the third is imaginary. British officers also will do well to visit Transcaspia and Turkistan. The military life there is akin to that which we lead along the NorthWest Frontier of India. There are many hints that we may pick up from the Russians in Central Asia to the advantage of our military and civil administration.

\title{
THE PHYSICAL CONDITIONS OF CENTRAL ASIA IN RELATION TO RUSSIAN COLONISATION.
}

\author{
(Being the Abstract of a Paper read before the Imperial Geographical Society \\ of St. Petersburg, March 1889.)
}

\section{By Limutenant-General Annenkoft.}

General Annenkoff commenced his lecture by referring to Southern Russia as a proof of the great results the energy of Russia is able to achieve in the field of colonisation. Within the last century and a half flourishing towns, such as Odessa, Rostov, Taganrog, Kherson, and Ekaterinoslaw have sprung up, and on steppes formerly supposed to be suited only for a nomadic life there now dwells a fixed population of 


\section{OROGRAPHICAL MAP OF CENTRAL ASIA.}

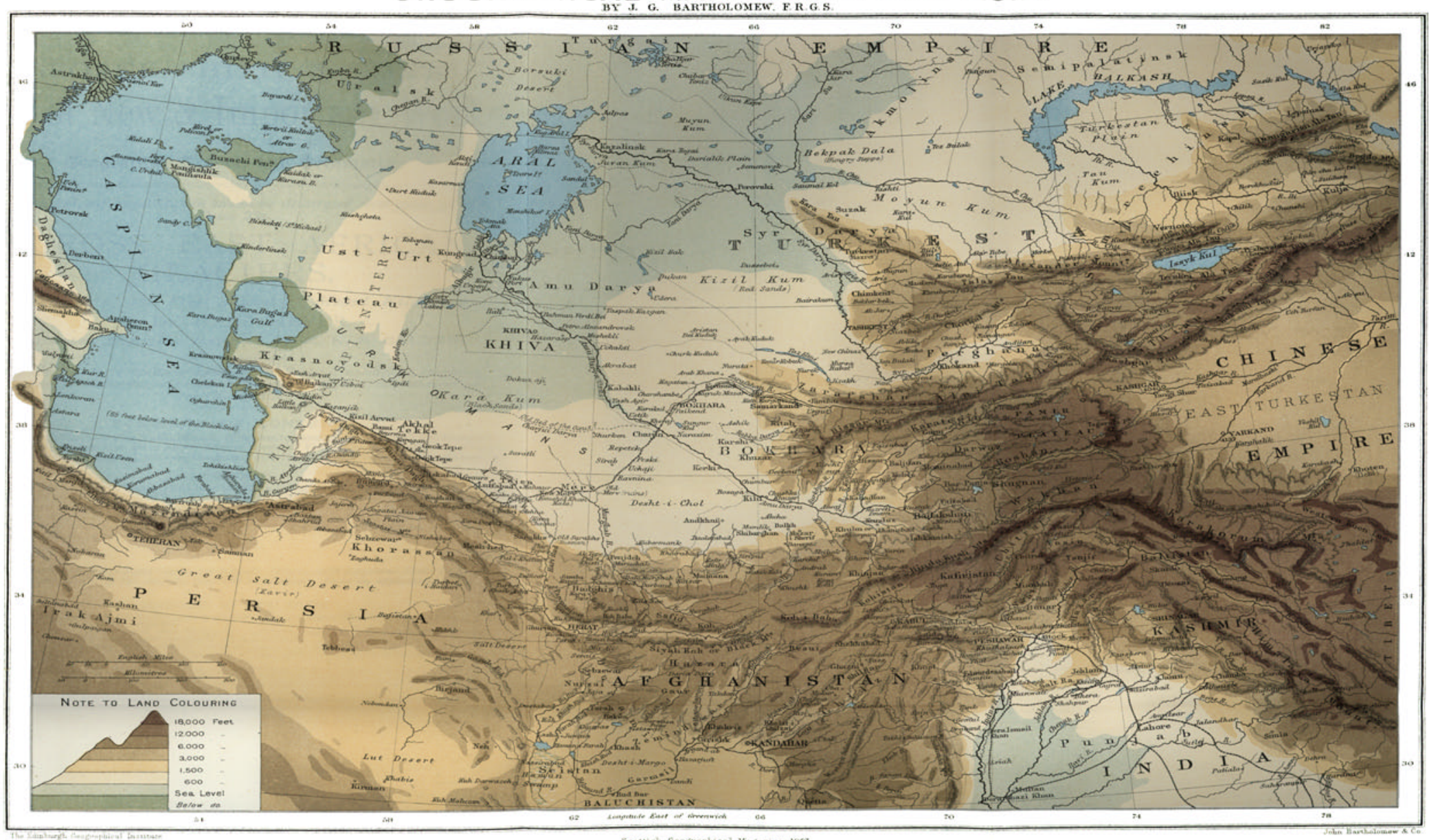

